\title{
Analysis of the effect of boron addition on steels for forged components
}

\author{
Andrea Di Schino ${ }^{1 *}$, Paolo Emilio Di Nunzio² \\ ${ }^{I}$ Dipartimento di Ingegneria, Università degli Studi di Perugia, Via G. Duranti 93, 06125 Perugia, Italy \\ ${ }^{2}$ Centro Sviluppo Materiali SpA, Via di Castel Romano 100, 00128 Roma, Italy
}

*Corresponding author

DOI: $10.5185 / \mathrm{amp} .2018 / 6993$

www.vbripress.com/amp

\begin{abstract}
Following the high cost of Mo and other alloying elements, many attempts are being carried out aimed to improve the hardenability of high thickness forged components without increasing their price. In this work the effect of B is examined on laboratory scale. In particular, two ingots have been cast in a pilot plant, with boron addiction. Boron as been added in a protected steel chemical composition, so to be effective in terms of hardenability. Materials were then hot rolled and cooled favoring the formation of a microstructure typical of that of forged components. Results on the material are compared to that of a standard steel in terms of hardenability. Copyright (c) 2018 VBRI Press.
\end{abstract}

Keywords: Steels, boron, hardenability.

\section{Introduction}

More and more high strength steels for forgings are required by the market. Main topics in manufacturing such products is in the fact that following the large size of this manufactured pieces, low cooling rate are usually achieved by standard industrial process, so that the high hardness required target values are not achieved far from the surface. The methods available for enhancing strength in steels for forgings are the following [1-2]:

1. Micro-alloying

2. Increasing the intrinsic steel hardenability

3. Adopting multiphase microstructure

In the first case the use of vanadium is preferred in comparison to that of niobium, due to lower precipitation temperature for $\mathrm{VC}$ particles responsible for precipitation strengthening. The fact that such temperatures appear to be lower favor the industrial applicability with lower energy costs [3] further opposing to grain growth process which should result deleterious for strength/toughness combination [4].

Concerning the hardenability increase, molybdenum or chromium are usually added, with enhanced costs. A valid alternative should be boron addition which is known to be able to enhance hardenability [1], in particular in the case of large components. To make boron addition effective a Q\&T process is needed after forging. Moreover, the addition of titanium is required favoring titanium nitrides formation and therefore avoiding the boron nitrides formation (thus leaving the atomic boron free to play its role in terms of hardenability) [5-8]. The effect of B effect on steel hardenability saturates at a value which is affected by depending on austenite grain size
(PAGS). It is reported that the highest boron amount able to affect hardenability for materials with PAGS from 20 to $100 \mu \mathrm{m}$ is about $30 \mathrm{ppm}$ [9].

This will reduce the presence of elements affecting hardenability, in particular expensive elements as Mo and $\mathrm{Ni}$.

Main novelty of this paper is the show how boron addition can be adopted in steels designed of forgings in substitution of more expensive elements as molybdenum of chromium.

\section{Experimental}

\section{Materials}

A standard 40CrMnNiMo8-6-4 was taken as a comparison steel. Basic analysis for the above material is: $\mathrm{C}=0.32-0.48 \%, \mathrm{Mn}=1.22-1.68 \%, \mathrm{Si}=0.17$ $0.43 \%, \mathrm{Cr}=1.73-2.17 \%, \mathrm{Mo}=0.12-0.28 \%$, No $=0.83-$ $1.27 \%$. Two ingots have been manufactured by a vacuum induction plant (VIM) adding B. They were then hot worked simulating the pass reductions and temperatures typical of an industrial forging process, with the main aim to avoid PAGS growth.

\section{Characterization}

Simulating the pass reductions and temperatures typical of an industrial forging process, with the main aim to avoid PAGS growth. From hot worked plates cylindrical specimens have been machined to be tested for dilatometry assessment by means of L 78 RITA Linseis dilatometer after austenitisation at $\mathrm{T}=850^{\circ} \mathrm{C} \times$ $600 \mathrm{~s}$. Continuous cooling transformation (CCT) were determined. 


\section{Results and discussion}

\section{Steel chemical composition design}

JMatPro4 software was used to simulate the behavior of different steels to understand which level molybdenum should kept if 30 ppm boron are added. taking as a guide the following Steel 1 chemical analysis: $\mathrm{C}=0.40 \%, \mathrm{Mn}=1.30 \%, \mathrm{Cr}=1.85 \%, \mathrm{Mo}, 0.22 \%$ (wt, \%).

Results shown in Fig. 1 reports that hardenability behavior is preserved if molybdenum is lowered from $0.22 \%$ to $0.15 \%$ and 30 ppm boron are added.

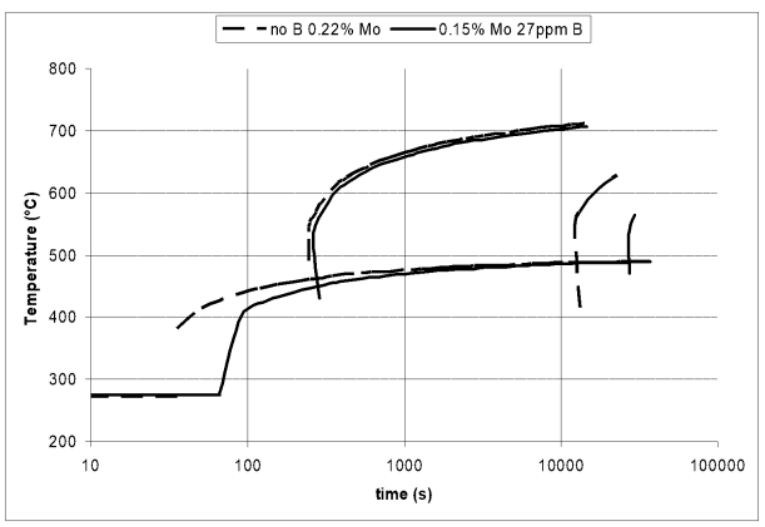

Fig. 1. Boron and molybdenum combined effect on Steel 1 hardenability.

Following the above results, the analysis of Steel 2 is designed. It differs from that of Steel 1 essentially for molybdenum content, maintained at the lowest range for these materials (Table 1). Aimed to analyze the effect of boron on a material with improved hardenability, Steel 3, differing from Steel 2 essentially for carbon, has been also taken into account. In Table 2 the estimated minimum cooling rates for martensite $\left(\mathrm{v}_{\mathrm{crM}}\right)$, bainite $\left(\mathrm{v}_{\mathrm{crB}}\right)$ and ferrite/pearlite formation $\left(\mathrm{V}_{\mathrm{crP}}\right)$ are shown. They were calculated following the following relation:

Table 1. Cheef analysis (wt, \%) for boron added steels.

\begin{tabular}{cccccc}
\hline & $\mathrm{C} \%$ & $\mathrm{Mn} \%$ & $\mathrm{Cr} \%$ & $\mathrm{Mo} \%$ & $\begin{array}{c}\mathrm{B} \\
\mathrm{ppm}\end{array}$ \\
\hline Steel 2 & $0.35-0.40$ & $1.40-1.60$ & $1.8-2.0$ & $0.15-0.20$ & 30 \\
Steel 3 & $0.45-0.50$ & $1.40-1.60$ & $1.8-2.0$ & $0.15-0.20$ & 30 \\
\hline
\end{tabular}

$\log 10 \mathrm{vcr}(\mathrm{i})=\mathrm{Kv}(\mathrm{i})-\left(\right.$ Error! $\left._{\mathrm{Fj}}(\mathrm{i}) \cdot \mathrm{wt} \% \mathrm{j}+\mathrm{KP}(\mathrm{i}) \cdot \mathrm{Pa}\right)$

where $v_{c r}(i)$ is the critical cooling rate in $K / h, K v, K P$, $\mathrm{Fj}$ are coefficients shown in [10] and the amounts $\mathrm{wt} \% \mathrm{j}$ are the element $\mathrm{j}$ fraction. It has to be remembered that (1) does not consider the boron contribution to hardenability, so that it can be assumed as a reference to be assessed by experiments. Table 2 reports that in Steel 3, without boron, the martensitic transformation is enhanced at higher cooling rates. On the contrary, at low cooling rates the higher carbon presence favors the pearlite nucleation.
Table 2. Critical cooling rates for Steels 2 and 3 (boron not included in simulation).

\begin{tabular}{cccc}
\hline & $\begin{array}{c}\text { VcrM } \\
\left({ }^{\circ} \mathrm{C} / \mathrm{s}\right)\end{array}$ & $\begin{array}{c}\mathrm{VcrB} \\
\left({ }^{\circ} \mathrm{C} / \mathrm{s}\right)\end{array}$ & $\begin{array}{c}\mathrm{VcrP} \\
\left({ }^{\circ} \mathrm{C} / \mathrm{s}\right)\end{array}$ \\
\hline Steel 2 & 0.10 & 0.0006 & 0.14 \\
Steel 3 & 0.02 & 0.0002 & 0.01 \\
\hline
\end{tabular}

To achieve an effective boron addition to enhance hardenability, boron nitrides nucleating must be opposed.

(a)

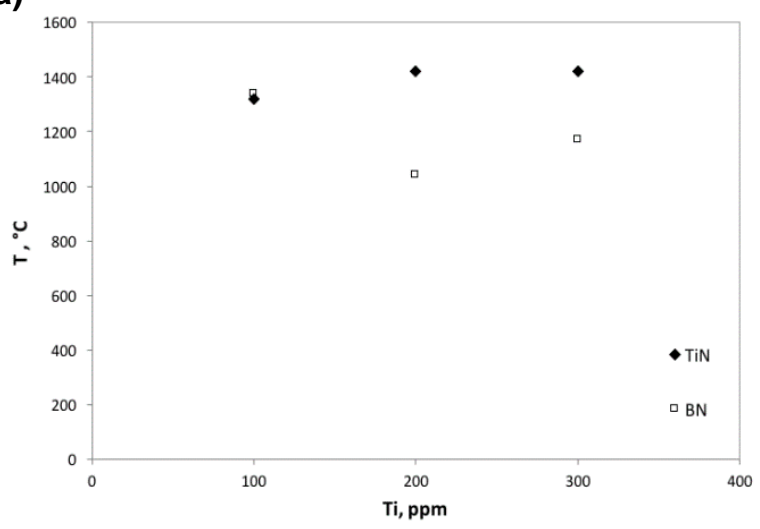

(b)

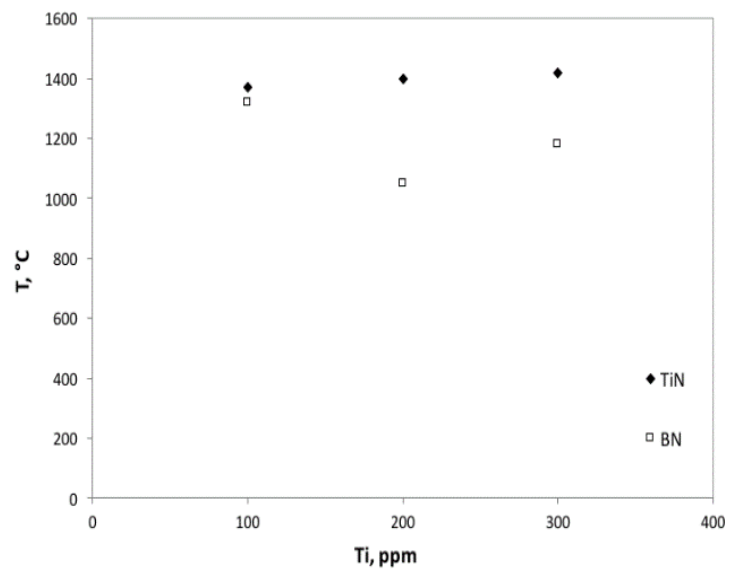

Fig. 2. Temperature of $\mathrm{TiN}$ and $\mathrm{BN}$ as a function of $\mathrm{Ti}$ content (a: Seel2; b: Steel 3).

This is usually targeted by titanium addition with the consequent formation of titanium nitrides. The titanium required to protect boron was calculated by the MatCalc software [11] using the steel database mc_fe_v2.017.tdb. Calculations performed on Steel 2 and Steel 3 report that, assuming a standard nitrogen content of $60 \mathrm{ppm}$, at least $200 \mathrm{ppm}$ titanium needs to be added (Fig. 2).

An increase of the titanium content does not affect the boron protection. Following these assumptions, the steels with the following chemical analysis were manufactured and processed.

Steel 2: $\mathrm{C}=0.38 \%, \mathrm{Mn}=1.48 \%$. $\mathrm{Si}=0.30 \% \mathrm{Cr}=1.90 \%, \mathrm{Mo}=0.15 \%$ Steel 3: $\mathrm{C}=0.48 \%, \mathrm{Mn}=1.58 \%$. $\mathrm{Si}=0.30 \% \mathrm{Cr}=2.00 \%, \mathrm{Mo}=0.17 \%$ 


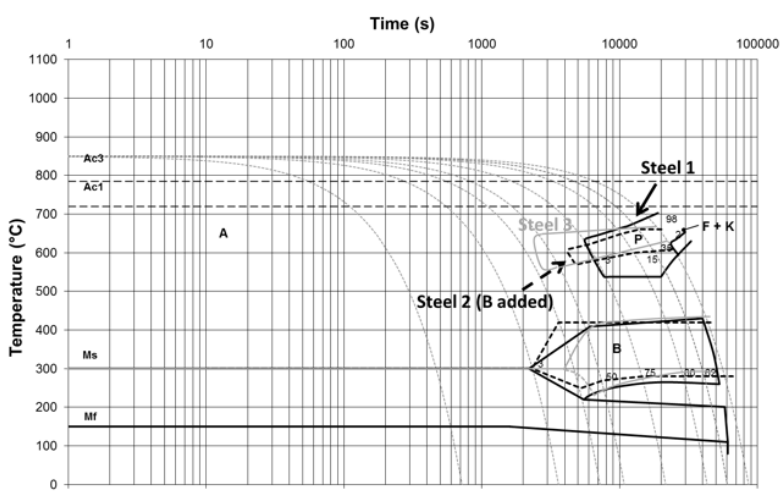

Fig. 3. Comparison of CCT curves.

\section{Hardenability}

Results from dilatometry report that the molybdenun and nickel reduction is replaced by $\mathrm{B}$ addition. In particular, a fully bainitic microstructure is targeted cooling down at $0.20^{\circ} \mathrm{C} / \mathrm{s}$ and the pearlite nucleation is avoided up to $0.06^{\circ} \mathrm{C} / \mathrm{s}$ (Fig. 3). From a comparison of Steel 2 and Steel it is clear that the higher carbon content in Steel 3 improves martensitic transformation. On the contrary, a higher $\mathrm{C}$ content also enhance pearlite transformation $\left(\mathrm{CR}<0.15^{\circ} \mathrm{C} / \mathrm{s}\right)$. As expected, carbon affects the steel hardenability also after the addition of boron.

\section{Conclusion}

Boron addition to a 40CrMnNiMo8-6-4 material with $0.38 \%$ carbon allows to reduce the molybdenum content from $0.22 \%$ to $0.15 \%$ without loosing hardenability. This implies a strong reduction of material costs. To analyse the effect of boron on hardenability, a proper addition of titanium is required so to avoid boron nitrides nucleation. The increase of carbon content to $0.50 \%$ promotes marten site formation at higher cooling rates, but also enhance the pearlite formation at lower cooling rates.

\section{References}

1. De Ardo, A.J.; Garcia, C.I.; Hua, M.; Metall. Ital., 2010, 9, 5.

2. Mengaroni, S.; Cianetti, F.; Calderini, M.; Neri, S.; Evangelista, E.; Di Schino, A.; Mc Queen, H.; Acta Phys. Pol., 2015, 128 , 629.

DOI: $10.12693 /$ APhysPolA.128.629

3. Ceschini, L.; Marconi, A.; Martini, C.; Morri, A.; Di Schino, A.; Mater. Des., 2013, 45, 171.

DOI: $10.1016 /$ j.matdes.2012.08.063

4. Di Schino, A.; Kenny J.M.; Salvatori, I.; Abbruzzese, G.; J. Mater. Sci., 2003, 38, 4725.

DOI: $10.1016 /$ S1359-6454(03)00059-4

5. Llewellyn, D.T.; Ironmaking Steelmaking, 1993, 20, 338.

6. Taylor, K.A.; Metall. Trans. A, 1992, 23A, 107.

7. Shigesato, G.; Fujishiro, T.; Hara, T.; Metall. Mater.Trans., 2014, $45,1876$.

DOI: $10.1007 / \mathrm{s} 11661-013-2155-3$

8. Li, Y.I.; Ponge, D.; Choi, P.; Raabe, D.; Scripta Mater., 2015 , 96, 13.

DOI: $10.1016 /$ j.scriptamat.2014.09.031
9. Hara, T.; Asahi, H.; Uemori, R.; Tamehiro, R.; ISIJ Int., 2004, 44, 1431.

DOI: $10.1016 /$ j.scriptamat.2014.09.031

10. Ph. Maynier, J. Dollet and P. Bastien, Rev. de Métall. 67 (1970) 343-351.

11. http://www.matcalc.tuwien.ac.at. 